\title{
THE MORTUARY CHAPEL OF UKHHOTEP SON OF IMA (A. NO.3) AT MEIR
}

\author{
Nour GALAL \\ Associate professor, Faculty of Arts, Ain-Shams University, Egypt \\ E-mail: noursmn2007@yahoo.com
}

\begin{abstract}
This article investigates the mortuary chapel of Ukhhotep son of Iam (A. No.3.) at Meir. Our information about Middle Egypt comes primarily from the cemeteries of the wealthy princes and mayors who were associated with political and religious centers of its administrative regions, or nomes; especially at Qaw el-Kebir, el-Rifa, Asyut, el-Bersha, Beni Hasan. El-Qusiya is another important site which is located almost $50 \mathrm{~km}$ northwest of Asyut. It was the cult center of Hathor. It was the capital of the Fourteenth nome of Upper Egypt. Meir was its necropolis. This nome was rich. Its rulers maintained a considerable state of nobility. They were a class of the mayors (nobility krht) which is reflected on their burials. Meir necropolis lies at the edge of cultivation. The tombs were cut into the rock cliffs. These tombs are characterized by the absence of portico on the façade. The chapel of Ukhhotep son of I am (A. No.3) is the focus of this article. It is located up on the cliff of Meir. The chapel has not been studied in details. I aim at providing the full history and description. The date of the chapel could be the time of Senwosert I
\end{abstract}

\section{KEYWORDS}

Meir, cemeteries, offerings, mortuary, chapel, Hathor, Ukhhotep, ritual, tomb.
يتناول هذا البحث المقصورة الجنائزية الخاصة بالنبيل اوخ حتب (A3) والتى تقع في مير ؛ جبانة القبانة

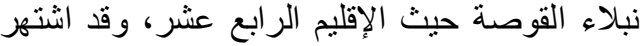

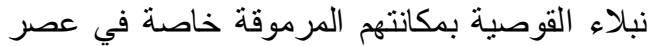

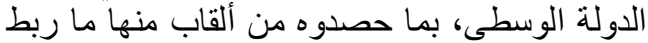

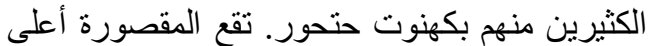
مقبرة بيى عنخ التى ترجع إلى عصر الدولة الدير القديمة،

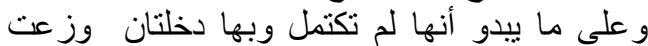
النصوص بما يشبه تقسيم الباب الوهي لهي حول الاخلة

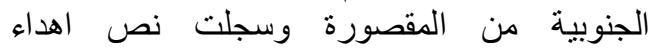
المقصورة إلى اوخ حوتب ثم شملت صيغة تقدمة

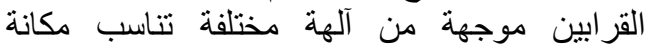
المقصورة وطابعها الجنزي، ولكن الأهم هو تسجيلها

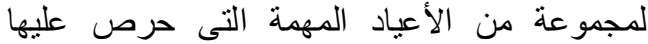
المصرى القديم وجاءت مرتبة وكاد الانت في في طابعها

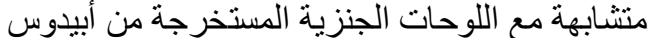

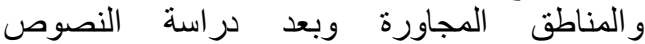
و الدراسات المقارنة فمن المرجح تأكيد تأريخها ببداية

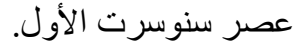

الكلمات الدالة

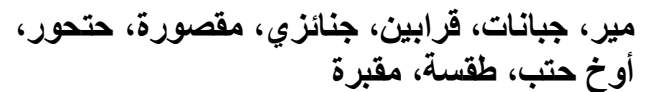




\section{ARCHITECTURAL FEATURES}

The chapel is clearly visible cut in the second terrace of the eastern face of the cliffs overlooking the western side of the town of el-Qusiya. ${ }^{1}$ The quality of this chapel is very bad. It is located above the tomb of Pepyankh $A 2^{2}$ (was also known by the name of Heny-Kem) (Fig.1). The chapel consists of a rectangular room (about $3.2 \mathrm{~m}$. from north to south and $3.70 \mathrm{~m}$. from east to west). It does not have a shaft for a burial. Although the chapel is unfinished, the general view of the first recess which belongs to Ukhhotep (pl.1 A), looks like false door ${ }^{3}$, and few traces of torus and cavetto cornice are still visible $^{4}$. The torus surrounds the panel and the niche. It makes the edges of the monument have a transversal fluted decoration ${ }^{5}$. These features were attested mid-Fifth Dynasty as a sign of high status of the owner. They became common in the Sixth Dynasty, although they coexisted along the older type. The main terms for mortuary chapels of private and royal individuals were $h w t k 3$ and $s t h h h,{ }^{\complement} h^{\top} t, m^{\top} h t$ and also $r$ $p r^{6}$ which could be used for an offering chapel as for false door by extension, along with the usual term $r w t^{7}$. According to F. Servajean, it is possible for the deceased to come in and come out his tomb, if a st nhhh "place of time" (funerary chapel) and a tpht $n \underline{d} t$ "cavern of eternity" (burial place) are at his disposal (possibly tpht could indicate both, a niche and a room). ${ }^{9}$

In the north wall of the chapel, there are two statue- recesses. The western recess is painted pink with dark reddish spots to imitate red granite. The two recesses designed to keep a statue of the deceased, Ukhhotep (Fig.2). Statues generally were placed in the chapel in order to provide permanent residing places for the soul of the deceased, substituting the body if it was destroyed. There is a socket at the top and bottom for the two doors- leaves to turn in. The rest of the interior ceiling, walls, and floor, is roughly hewn. The walls of the chapel were coated with mud plaster, but not apparently the

\footnotetext{
${ }^{1}$ Blackman, Meir VI, pls. 2, 5; Meir I, pp. 8, II-12 [4].

${ }^{2}$ It is believed that Pepyankh was the first one who chose this place for his burial; Sébastien Polet, 'Généalogie et chronologie chez les nobles de Meir et de Koçeir à l'Ancien Empire', in Studi di Egittologia e di Papirologia 5, (2008), p. 81-94 and id., 'Pepy-ankh Heny le noir de Meir (tombe A2) a-til usurpé le titre de vizir?', in Res Antiquae 7, (2010), p. 417-428; N. Kanawati, The Cemetery of Meir II. The Tomb of Pepyankh the Black, Australian Centre for Archaeology Reports 34, (2014).

${ }^{3}$ See Brovarski, 'False Doors and History: The First Intermediate Period and the Middle Kingdom', in D. P. Silverman, J. Wegner, eds., Archaism and Innovation. Recent Perspectives on Middle Kingdom Egypt, Philadelphia, Prague, (2009), pp. 359-424.

${ }^{4}$ Torus and Cornice were attestedearly of the Fifth Dynasty, and were found mainly from the reign of the King Niuserreuntil late Fifth Dynasty. They were confined principally to viziers and high officials. They became the usual types in the Sixth Dynasty. They were favorite decorative elements for the fronts of the Twelfth Dynasty statue niches in Qubbet el-Hawa and Meir see: H. W. Müller, Die Felsengräber der Fürsten von Elephantine, $\ddot{A} F$ 9, Glückstadt, (1940), figs. 34, 39, pl. 31; Blackman, Meir I, pls. 15 [1], 22 [1]; II, pls. 9, 33 .

${ }^{5}$ Vandier, Manuel II, pp. 401-402.

${ }^{6}$ Spenser, P., Studies in the Lexicography of Ancient Egyptian buildings and their parts, London, (1981), p. 168; Lichtheim, Ancient Egyptian Autobiographies, Orbis biblicus et orientalis, (1988), pp. 101, 102, 110.

${ }^{7}$ Spenser, P., Studies in the Lexicography of Ancient Egyptian buildings and their partss, p. 140. ${ }^{8}$ Servajean, F., Djet et Neheh. Une histoire du temps égyptien (= Or Mons XVIII), Montpellier, (2007), p. 69. Some texts from the new kingdom tombs like TT 38 points to the funerary chapel as a place of $m 3^{c}$ hrw see: Davies, Scenes from some Theban Tombs, Oxford, (1963), pl. VI, p. 6.

${ }^{9} \mathrm{~Wb}$ V, 364 (11). The function of the chapel discussed further by Legros, R., Stratégies mémorielles. Les cultes funéraires privés en Égypte ancienne de la Vie à la XIIe dynastie, Lyon, (2016).
}

- 110 - The Mortuary Chapel of Ukhhotep Son of Ima (A. No.3) at Meir 
painted recess, its jambs or lintel. The hieroglyphic signs are incised and painted blue (Fig.3). Inside, on the three walls, there is a black dado surmounted by blue, red, and yellow bands. In front of the left recess, there was probably an offering slab. With regard to the shafts, despite the time which Blackman spent at Meir (on and off for nearly 40 years) and the attempts of Kanawati, they did not find shafts for A3, B1, B4 and $\mathrm{C} 1$. It is a very puzzling thing. Where were the owners of these tombs buried? The scholars do not know. Tomb B2 and B3 have shafts, but the curious thing is that the decoration of both of these tombs are totally unfinished. The owners of B1, B4 and C1 perhaps chose to have their shafts at a far distance from their tombs, so no one would violate or rob them. ${ }^{1}$

\section{THE OWNER OF THE CHAPEL AND HIS TITLES}

There is no titles assigned to Ukhhotep in the chapel (A3) except the most common one h3ty- ${ }^{-}$. This title perhaps was a local title, simply served to enhance the prestige and denote the status of the dominant local leader, without any further administrative consideration. ${ }^{2}$ M. Pardey, added that it is an elusive term meaning literally "foremost of position"; heoften translate it as "baron", general mayor also could be a rank title ${ }^{3}$. There are many cases where the title hity- ${ }^{-}$appears immediately before the name of the official $^{4}$. Other epithets $m 3^{\top} \underline{h r} w$, vindicated, and $i m 3 h w$, venerated, were attested. They assert that the owner has achieved or is destined to achieve, a place among the honored and transfigured beings in the afterlife. ${ }^{5}$ Non royal memorials tend to present the highlights of the official's entire career consecration of their tomb or votive chapel. This chapel does include a long autobiographical text ${ }^{6}$, while numerous epithets are distributed throughout the tombs of Ukhhotep II $^{7}$, Ukhhotep III and Ukhhotep IV. ${ }^{8}$ Their titles were held by many other high and middle rank officials. No sign that these local governors claimed royal power. W. Grajetzki attributed the presence of the royal

\footnotetext{
${ }^{1}$ Kanawati's point of view via personal contact.

${ }^{2}$ Knawati, Hawawish, p. 35, not.4; For the titles the following references are generally consumed; Ward, W. A., Index of Egyptian Administrative and Religious Titles of the Middle Kingdom and related Subjects ,Beirut, (1986), p. 47, n. 367; Fischer H. G., 'Egyptian titles of the Middle Kingdom: A Supplement to Ward's Index', MMA, New York, (1985)., Helck W., Verwaltung, P. 209; id., 'Titel und Titulaturen', $L \ddot{A}$ $V I$, col. 600; As mayor, the title often stands alone in inscription in front of the name, but was also often combined with the titles overseer of priests or overseer of the god's house, indicating that local governors were also the head of local religious matters; Quirke S., Titles and bureaux of Egypt 1850-1700 BC, London, (2004), pp. 111-112; Jones, D., An Index of Ancient Egyptian titles, 496 [1858].

${ }^{3}$ Pardey, M., Untersuchungen zu agyptischen Provinzialverwaltung bis zum Ende des Alten Reiches, HÄB 1, Hildesheim, (1976).

${ }^{4}$ Willems, H., Nomarchs and Local Potentates,' The Provincial Administration in the Middle Kingdom' in C. Moreno, ed., Ancient Egyptian Administration, Leiden, (2013), p. 361.

${ }^{5}$ Doxey, D., Egyptian Non - Royal Epithets in the Middle Kingdom, (1998), p. 1.

${ }^{6}$ This may indicate that the chapel was not finished; Gnirs E.g., Die ägyptische Autobiographie, in A. Loprieno, ed., Ancient Egyptian Literature: History and Forms (=PA 10), Leiden (1996), pp. 203-204; id., Biographies, in Redford, ed., The Oxford Encyclopedia of Ancient Egypt, I, (New York 2001), pp. 184-189; Lichtheim, Ancient Egyptian Autobiographies, (Orbis biblicus et orientalis 1988).

${ }^{7}$ Ukhhotep II has several charges such as ḩ3ty ${ }^{c}$, iry p't,hry-ḥb; Grajetzki, W., Court officials of the Egyptian Middle Kingdom, London, (2009), p.5.

${ }^{8}$ Willems, H., 'Nomarchs of the Hare Nome and early Middle Kingdom history', Jaarbericht Ex Oriente Lux. Jaarbook van het Nederlands Instituut Te Leiden, vol. 28, (1983-1984), pp. 82-84.
} 
symbols in the decoration of tomb of Ukhhotep IV at Meir ${ }^{1}$ and in the tomb of Wahka II at Qaw el-Kebir to the cult of Hathor and her relationship with the kingship in these two cemeteries. $^{2}$

Inscriptions (pl. 2) ${ }^{3}$ : On the façade the inscriptions are divided into four horizontal lines, reading from right to left. The main text consists of four horizontal lines of incised colorful hieroglyphs on the upper lintel, oriented from right to left. The text on the right and left outer jambs comprises two vertical columns which consist htp di $n s w$ formula.

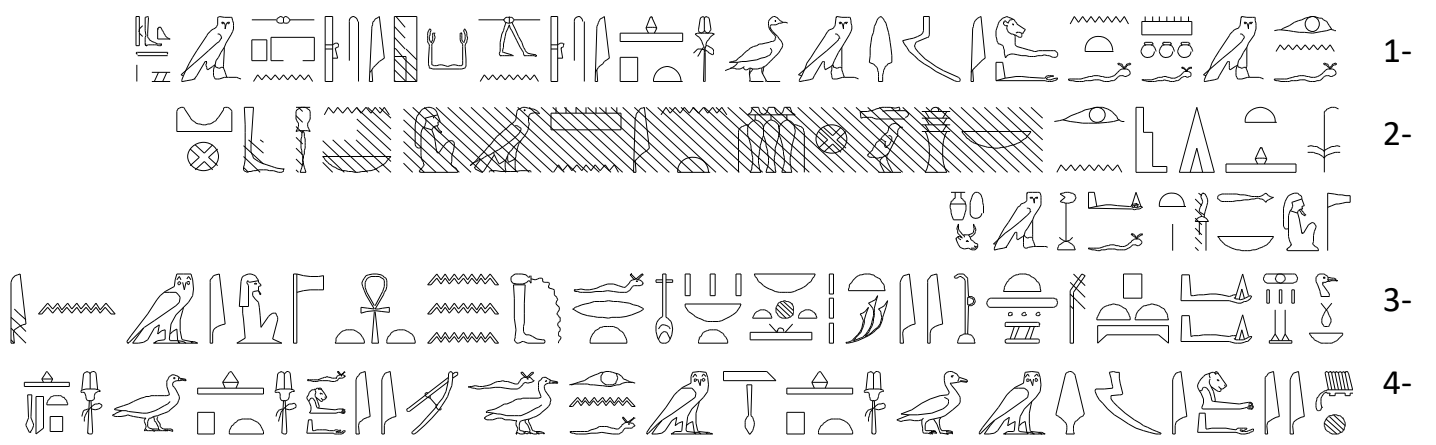

The inscriptions on the façade of the western recess (upper lintel):

$\rightarrow$ (1) ir.n.f m mnw.fn it.f ḩ3ty-` Wh-ḥtp s3 T3m iss $n\{h w t\} K 3 .\{f\}$ is pn $m-K 3 b$

(2) htp di nsw Wsir \{nb $\underline{D} d w$ Hnty-imntyw nb $3 b \underline{d} w\}$ ntr 93 nb imnt di.f h3 $m$ t hnkt k3w

(3) 3pdw šs mnht ddt pt Km3t t3 rnpwt nbt ḩt nbt nfrt w'bt 'nht nț im n

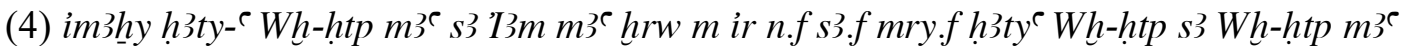
hrw

(1) He made as his monument for his father ${ }^{4}$, the Governor Ukhhotep, son of Iam, who has gone to his ka-domain of this tomb-chapel inside $\{\mathrm{it}\}$

(2) An offering which the King gives, an offering which Osiris gives [lord of $\underline{d} d w$, the foremost of the westerners], lord of Abydos, great god, lord of the west ${ }^{5}$, he gives: a thousand of bread, beer, oxen,

\footnotetext{
${ }^{1}$ The governor Ukhhotep IV at Meir had a wish that he may become a king. In this context, there is no sign that the local governors assumed royal power. They just followed new religious beliefs; Grajetzki, W., The Middle Kingdom of Ancient Egypt, London, (2006), p. 98; Fischer, Gaufurst, LÄ II, 411. ${ }^{2}$ Grajetzki W., Tomb Treasures of the late Middle Kingdom, Pennsylvania, (2013), p. 184.

${ }^{3} \mathrm{Cf}$. The Previous old Cledat's copy of the hieroglyphic text which is full of many mistakes, Cledat, 'Notes archiologiques et philologiques', BIFAO II, (1902), p. 43; Blackman, Meir VI, pl. 2; Blackman, Meir VI, 1-2.

${ }^{4}$ On the formula: jr n.f $m m n w . f$, see Kruchten J, M., 'Deux cas particuliers de phrase coupée sans l'opérateur énonciatif, JEA 82, (1996), pp. 51-63; Grallert S., Bauen, Stiften, Weihen. 'Ägyptische Bauen- und Restaurierungsinschriften von den Anfängen bis zur 30. Dynastie', ADAIK 18, 2001, pp. 3460; Depuydt L., 'On the Meaning of a Formulaic Expression in Egyptian', LingAeg 9 (2001), pp. 83-122; id., Egyptian Reconstituted, BiOr 62 (2005), col. 26-29; Wb III, 70.

${ }^{5}$ Different variations: $n b$-imntt, $n b$ imntt $n t-3 b \underline{d} w$, $n b$-imntt $d w 3 t$ for more see: $L \ddot{A} A$ III, $583 \mathrm{f}$.
}

- 112 - The Mortuary Chapel of Ukhhotep Son of Ima (A. No.3) at Meir 
(3) Fowl, alabaster (vessels), and garments ${ }^{1}$ of what sky and earth produce, and all fresh-vegetables and every good and pure thing ${ }^{2}$ that a god lives on, for

(4) the honored one, the count Ukhhotep, son of Iam, The Justified; as what his beloved, his son has made for him the Governor, Ukhhotep's son, Ukhhotep, Justified. ${ }^{3}$

\section{COMMENTARY}

The façade consists of four horizontal lines. Line 1, is badly preserved. The text can be studied only with difficulty. I propose some different signs from the Blackman's facsimile (Meir VI, pl. V). Blackman's translation "he made (it) as his monument for his father, the Governor, Iam's son, Ukhhotep, justified...this tomb-chapel is in?" (Meir IV, p.2). Fortunately, it was possible for me to examine the chapel personally, however, allows a slightly revised transcription and translation which cited above. The opening phrase line in this chapel begins with the emphatic $s \underline{d m . n . f} f$ itis identical to the tag found on the 'Mayors List' in B4. ${ }^{4}$ The signs at the end of line no. 1 are smaller and less deeply incised.

The second line is also badly damaged, including $h t p-d i$ - $n s w$ offering formula ${ }^{5}$, which is repeated twice later. This line may be restored as [htp di nsw Wsir [nb $\underline{d} d w$ hnty Imntyw] $n b 3 b \underline{d} w]$. The line offered sufficient space for this, compare, for example the Osiris epithets in the offering list of private tombs ${ }^{6}$, and Beni Hassan. ${ }^{7}$

One thousand of $h 3-m$ is required of each food item. The deceased used to record his wish of certain offerings, some of which were traditional while others were more specific to his taste. ${ }^{8}$

\footnotetext{
${ }^{1}$ Another word for linen: šrrw Wb IV 295(13); Pyr. D.18 this word for linen, is well attested from early texts.

${ }^{2}$ For iht nb nfrt cf. Barta, W., Die altagyptiche Opferliste, MÄS 3 (Berlin 1963), p. 144.

${ }^{3}$ Anthes, R., 'The original meaning of M3e hrw, JNES 13 (1954), p. $21 \mathrm{ff}$.

${ }^{4}$ Blackman, Meir III, pl. II, 29.

${ }^{5}$ Barta W., Die altagyptische opferliste von der Frühzeit bis zur griechisch-römischen Epoche MÄS 3, Berlin (1963); cf. the debate about the work of Barta by K. Kitchen, Orientalia 41 (1972), pp. 129-132; Smither, P., 'The writing of htp-di-nsw in the Middle and New Kingdom', JEA 25 (1939), pp. 34-37; Bennett, C., 'Growth of the htp di nsw Formula in the Middle Kingdom', JEA 27 (1941), pp.77-82; id., 'Motifs and phrases on funerary stelae of the Middle Kingdom', JEA 44 (1958), pp. 120 -121; for new reinterpretation of the offering formula see, D. Franke , 'The Middle Kingdom offering formulas- a challenge', JEA 85 (2003), pp. 39-57.

${ }^{6}$ Fisher H., ZÄS 90 (1963), 37.

${ }^{7}$ Newberry, Beni Hasan III, pl. 27; Lange and Schäfer, Grab- und Denksteine des Mittleren Reiches, II, 20400, 20402, 20406, 20425.

${ }^{8}$ The word that expressed the desires was $s t p w=$ the best things $\mathrm{Wb}$ IV 338-339 (14) noun derived from the verb stp denoting the best things in general.
} 
This chapel was dedicated to the $k 3$ of Ukhhotep to have an everlasting source of food, drink and other vital offerings in the afterlife. The Ennead may perform as a less strict commission of reception in the realm of the dead, so the offering formula was by their names with Osiris and Anubis who associated with the burial ground on higher desert ground ( $t 3$ $n$ tr).Inscribed offering formulas would magically sustain the tomb owner's spirit when the mortuary priests and relatives read the text, if they ceased to provide real offerings of food and drink ${ }^{1}$. Bread was essential item of offering for the deceased individual and the gods alike, presented in daily rite. Wine also was often an important item in funerary cults, besides its general significance as an item of wine took a certain specific religious and mythological associations, in the pyramid texts; Osiris was mentioned as the lord of wine in the Wag Festivals $(P y r 442 ; \& 820 a)^{2}$. The ka of the deceased had access to all

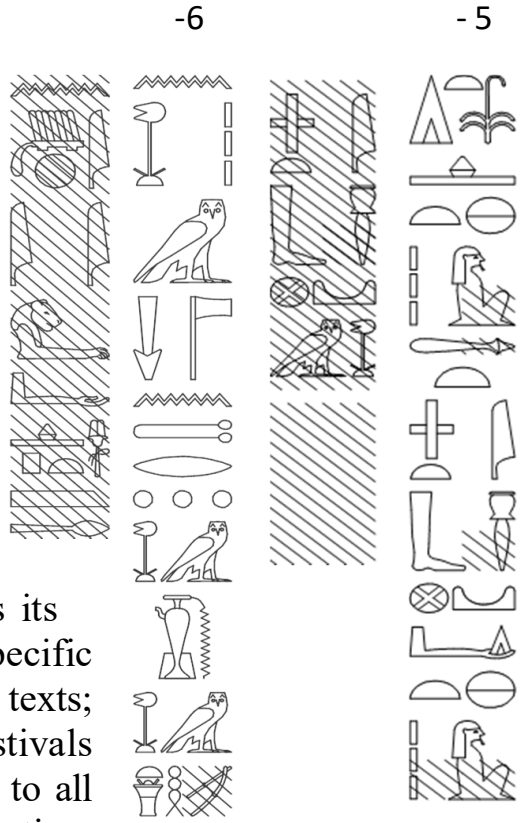
things good and pure on which a god lives. Acts of libation, purification and censing were associated with the rejuvenated deceased ${ }^{3}$. The forth line repeats the names and title again. It describes Ukhhotep as an honored one im3hy (venerated, the one who has been provided for transfigured dead) ${ }^{4}$. Ukhhotep was the son of Ukhhotep who was the son of I am. Thus I am the grandfather of the last Ukhhotep ${ }^{5}$. The Egyptian llanguage has no special words for grandfather, grandmother, Grandson, and granddaughter, although references to father's father and similar terms were attested ${ }^{6}$.

\section{THE INSCRIPTION ON THE LEFT JAMB}

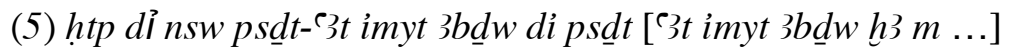

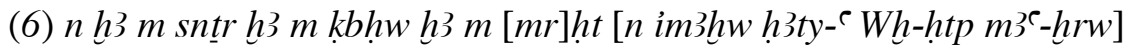

(5) An offering that the King gives, and the [great] ennead who is in Abydos, [the great ennead who is in Abydos] may give: [a thousand of ...], (6) a thousand of incense, a thousand of libations, a thousand of unguent-jars, [for the honored-one, the governor Ukhhotep, justified].

\footnotetext{
${ }^{1}$ Barta, Die altagyptische opferliste, p. 15

${ }^{2}$ Helck W., Das Bier im alten Ägypten, (Berlin 1917); See Poo : Poo, Mu-Chou, Wine and wine offering in the religion of ancient Egypt. Studies in Egyptology, London- New York, (1995)

${ }^{3}$ Blackman A., 'The Significance of Incense and Libations in Funerary and Temple Ritual', Z̈̈S 50 (1912), pp. 69-75.

${ }^{4}$ Jones, Index, vol. I, p. 11 [42]; for the interpretation of im3h, see: Jansen K. W., 'Zur Bedeutung von im3h', Bulletin de la Societé d'Égyptologie de Genève 20, (1996), pp. 29-36; For im3h hr ntrr 3 see H. Junker, Gîza II, (Wien 1934), p. 53f; LÄ I. 1087-9.

${ }^{5}$ See below.

${ }^{6}$ Even it / $m w t$ could be used for father/mother in law for more details see: Robins, G., 'The Relationships specified by Egyptian Kingships Terms of the Middle and New Kingdoms', CdE 54, (1979), 197-217; Bierbrier, M. L., 'Terms of Relationship at Deir el-Medina', JEA 66, (1980), 100-107.
}

- 114 - The Mortuary Chapel of Ukhhotep Son of Ima (A. No.3) at Meir 


\section{COMMENTARY}

The text starts again with the offering formula of htp di nsw to the great Ennead in Abydos. This Ennead is composed of seven gods: two Khnum- gods, Thoth, Horus, Hor-nedjitef ()$^{1}$, and two Wepwawet-gods, or of twelve gods: Osiris, Hor-nedjitef, Isis, Nephthys, Min, Iunmutef, Re-Harachti, Onuris, Tefnut, Geb, Thoth and Hathor ${ }^{2}$. Different kinds of offerings occurred (particularly in the late Twelfth and Thirteenth Dynasties stelae). They are usually more fully written out: sntr $h 3 \mathrm{~m} \mathrm{kbh} \mathrm{h3} \mathrm{m} \mathrm{mrht}$ offering of incense sntr (make divine) conforms to its use in earlier periods in rituals ${ }^{3}$. Incense being the sign of god's presence and a medium for communicating with him. The action verb was sti is normally used for scattering solid substances such as incense ${ }^{4}$. The libation offering $k b h$ is paired with the offering of incense in the funerary offering which is mad to the deceased.

\section{THE INSCRIPTION ON THE RIGHT JAMB}

(7) htp di [nsw] Inpw hrp t3wy tpy $\underline{d} w$.f imy wt nb t3-dsr di.f prt-hrw t hnkt k3w 3pdw šs mnht $m$ (8) 3bd mddint (/smdt) hryw-rnpt 5 wpt-rnpt W3g msyt $n$ ḩ3ty-e Wh-ḥtp

(7) "An offering that the king gives of Anubis, director of the two lands, who is upon his mountain, the embalmer, lord of the necropolis. He gives invocation-offerings: bread, beer, oxen, birds, alabaster-vessels, and garments, (8) the monthly-festival, the half-monthly festival, the five epagomenic days, the new year's day, the Wag-festival, and the supper (:of the beginning of the year), for the Governor Ukhhotep".

\section{COMMENTARY}

In these two lines, the text mentions the offering formula, the dates on which these offerings should be presented, linking them to specific festivals. Food could also be actualized by recite a "voice offering". There were texts on some stelae had instructs visitors if they have nothing in their hand to say a thousand of bread, beer.... and every good thing . The "prt-hrw", formula does not appear after di.f and before the group of offerings 6 , While this group of signs literally means 'sending the voice'. It actually

\footnotetext{
${ }^{1}$ Rolf Felde: Ägyptische Gottheiten, Wiesbaden 1995, P. 19; LÄA 5: H - h. pp. 268-269.

${ }^{2}$ Te Velde, H.,Relations and Conflicts between Egyptian Gods, p. 243 p. 243 (on line accessed on the $2^{\text {nd }}$ March 2017).

${ }^{3}$ Blackman, A., 'The Significance of incense and Libations in funerary and temple ritual', Z̈̈S 50 (1912), pp. 69-75.

${ }^{4} \mathrm{~Wb}$ IV, 346 (13).

${ }^{5}$ Dunham, D., The Nag-ed Der stelae of the first Intermediate Period, London, (1937), p. 102, pl. 31.

${ }^{6}$ See: Brovarski, False Doors and History: The First Intermediate Period and Middle Kingdom. In Silverman, Simpson, and Wegner, eds. (2009), pp. 359-423; E. Brovarski, Inscribed Material of the First Intermediat Period from Nega-ed - Der, UMI, (1989), 250 n. 299; Spanel, in: Studies in Honor of William Kelly Simpson II DP 767-68. For the tendency by adding more commodities before the Twelfth Dynasty see Fischer H G., Dendera in the Third Millennium B.C. Down to the Theban Domination of Upper Egypt, New York, (1968), p. 83, n. 359.
}

The Mortuary Chapel of Ukhhotep Son of Ima (A. No.3) at Meir $\mid \mathbf{~ 1 1 5 ~ - ~}$ 
indicates "presenting offerings". ${ }^{1}$

\section{This chapel interested in belongs to the sequence $h t p-d j-n s w$ formulas ${ }^{2}$}

The presentation of offerings often interpreted as the return of the Eye of Horus to its owner, thus suggesting a well-known episode in the myth of the conflict between Horus and Seth. ${ }^{3}$ Osiris, great Ennead and Anubis are asked to provide invocation offerings and permit the deceased to travel through the beautiful roads of im3hw. ${ }^{4} h t p-d j-n s w t d j$ Wsjr (line 2): a feature that indicates a date at the end of the Sixth Dynasty or laterThe root $h t p$ means both offering and peace. Offerings were made by private persons such as who are depicted in the tombs. The offerings could be fully effectual, if they were presented in the name of the king. The developments in the Middle Kingdom raised the status of both Osiris and Abydos. The cult of the funerary god became extremely popular during this period. ${ }^{5}$

The term ntr 93 "Great God" is usually specified; it could refer to Ra, Osiris, or to the deceased king himself. However, it seems that in most non-royal texts it probably refers to the god Osiris. Osiris is also called Khenty-Imentyu. It is also more common in the first half of the Twelfth Dynasty. However, Khenty-Imentyu is not written with the determinative of a seated god, which was a common writing for this divine name only later. It is not before the mid-Fifth Dynasty that the Osiris legends, which represent well the idea of resurrection and after life, came to be associated with the funerary beliefs of the individual. ${ }^{6}$ Peter Der Manuelian published an important false door of the lady Jntj from Giza (Boston, MFA 31.781) with the offering formulae mentioning Osiris twice. He dated it to late Fourth Dynasty. Then this god began to take his place beside Anubis in the prayers and soon was considered the principal deity of the dead. ${ }^{7}$

\footnotetext{
${ }^{1}$ Urk. IV: 1189:1: pr(t) hrw n.f nfr $m$ hwwt $k 3$ nt $\underline{d} t$.f $m$ js.f $n$ hrr(j)-ntrr"Making good offerings (lit. sending a good voice) for him in his own ka enclosure (and) in his tomb of the necropolis".

${ }^{2}$ About the offering formula, see Barta, Aufbau und Bedeutung der altägyptischen opferformel, Äg Fo 24, Gluckstadt, 1968; Lapp, G., 'Die opferformel des Alten Reiches', JNES 53, Number 2/Apr., (1994). For its late development see: Franke, D., The Middle Kingdom offering Formulas- Challenge, A., JEA 89, (2003), pp. 39-57; Bennett, C., 'Growth of the htp di nsw Formula in the Middle Kingdom', JEA 27, (1941), pp.77-82.

${ }^{3}$ For the interpretation of offerings as the Eye of Horus, see: Rudnitzky, G., Die Aussage Uber das Auge des Horus, (Kopenhagen 1956);Roeder, H., GM 138 (1994), pp. 56-67.

${ }^{4}$ Barta, altägyptischen opferformel, p. 15.

${ }^{5}$ The early occurrence of the epithet Osiris 'deceased' in the inscriptions of non-royal individual's false door was in Ninth and Tenth Dynasties (JE 59158). The most characteristic epithet of Osiris is $w n-n f r$ 'enduring in well-being/the good', was the Egyptians praise of the rejuvenation of the god.

${ }^{6}$ On the royal monuments, Osiris is attested first in the Pyramid Texts of Unis, while in the private tombs, as far as we can date them, his name does not occur (in the offering formula) before Isesi; See bibliography in Bolshakov, A. O., 'Princess ḥm.t-řs (w): The First Record of Osiris?', CdÉ 67 (1992), p. 203; van de Walle, B., La chapelle funeraire de Neferirtenef. (Bruxelles 1978), p. 24, note 70. Also W. Helck, 'Uberlegungen zum Ausgang der 5. Dynastie', MDAlK 47(1991), p. 164 (with some reservations concerning our general ability to date Old Kingdom tombs precisely) and Eaton-Krauss, M., 'The Earliest Representation of Osiris', VA 3, (1987), pp. 233-236.

${ }^{7}$ der Manuelian, P., 'A Case of Prefabrication at Giza, The False Door of 'Imj', JARCE 35 (1998), pp. 115 127.
}

- 116 - The Mortuary Chapel of Ukhhotep Son of Ima (A. No.3) at Meir 


\section{htp-dj-nsw psdt (Line 5) ${ }^{\mathbf{1}}$ :}

Ennead ( $p s \underline{d} t)$. Originally indicated the nine gods incorporating the physical creation of the world ${ }^{2}$ : Atum; Shu and Tefnut; Geb and Nut; Osiris and Isis, Seth and Nephthys, known as the 'great Ennead' ( $p s \underline{d} t$ ' $3 t)$; it is also a term for any number of gods conceived as a group, and for all the gods ${ }^{3}$. The 'great Ennead' also represented the gods of Lower Egypt, compared to the 'Elder Ennead' (psd $t w r t)^{4}$, also known as the 'Little Ennead' ( $p s \underline{d} t$ t $\underline{d} s t$ ), which consisted of the gods of Upper Egypt. Together, these two Enneads were known as 'the Dual Enneads' (ps $\underline{d} t j) . "$

$h t p-d j-n s w$ Anubis (Line 7): It is noted that the formula of offerings was dedicated to Anubis in line (7). Osiris and Anubis are patrons of the western desert and the netherworld associated with funerary offerings. ${ }^{5}$ Anubis was providing burial and sustenance for the deceased, but Osiris could provide eternal life. ${ }^{6}$ The writing of the name of Anubis with the sign of a jackal 5 is characteristic of the period till the beginning of the Sixth Dynasty, the jackal on a shrine the King Teti; however, the old variant was not completely discarded, especially when s.

Festivals (Line 8): The list of feasts is one of the main points of focus in this chapel. The regular offerings were presented during specific festivals and periods ${ }^{8}$.

The mortuary contracts which the local governor $d f(i)-h^{\top} p y$ made with the priesthood of Asyut early Twelfth Dynasty focused on specific festivals and on cults which should be performed for his statues in the temple. One of the main groups of contracts refers to the tomb and a statue which may have been there. ${ }^{9}$ The tomb of hnm-htp II at Beni Hassan provides useful information concerning the day feasts. In the chapel of wh$h t p(\mathrm{~A} 3)$, the list of feasts on the north wall comprise: $3 b d$, smdt, Epagomenal days, $w p$

${ }^{1}$ cf. Offering formula which was under the protection of Osiris and Soker and Ennead of the white wall (Louvre LD 65)

${ }^{2}$ The term ennead is not as a circle of nine gods, but as a circle of a plurality of gods.

${ }^{3}$ The Elder Ennead ( $p s \underline{d} t$ $3 t$ ) was first of all considered as Heliopolis's Ennead (cf. $\S \S 14 \mathrm{c}, 770 \mathrm{~d}, 845 \mathrm{~b}$, 895b, 1655a, 1660a; CT V, 208b; Blackman, Meir II, pl. 6; Budge, BD151:11 (first version), BD151:8-9

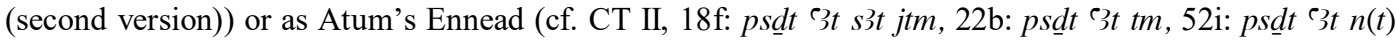
$\mathrm{tm}$ ) rather than as the Ennead that represented the gods of Lower Egypt.

${ }^{4}$ The Great Ennead (ps $\underline{d} t w r t$ ) was also located in Heliopolis, §1689c: jn ps $\underline{d t j} w r t$ ( $3 t$ hnt $(j) t(j) b 3 w$ jwnw "say the Great and Elder Enneads that are at the fore of the base of Heliopolis", and probably was headed by Geb.

${ }^{5}$ They also appeared in Middle kingdom coffins; sometimes tend to replace the two gods with Nephthys and Isis who were represented during the burial rites by priestesses positioned at the corpse's head and feet.

${ }^{6}$ The connection with embalming ritual and the identification of $s h n t r$ of Anubis or $i b w$ or $w^{c} b t$ see: Grdseloff, B., 'Nouvelles données concernant la tente de purification', ASAE 51 (1951), pp.129-140; Altenmüller, H., 'Die Bedeutung der Gotteshalle des Anubis"' im Begräbnisritual', JEOL 7 no.22 (19711972), pp.307-317; Lehner, M., Complete Pyramids, p. 27; Oxford, Following Osiris Perspectives on the Osirian Afterlife from Four Millenia p. 556 (online).

${ }^{7}$ EI-Khouli, A.\& Kanawati, N., Excavations at Saqqara. North West of Teti 's Pyramid II., (Sydney 1988), pls. 7-8.

${ }^{8}$ Graefe, E., 'Talfest', L̈̈ VI (1986), cols. 187-9; Grajetzki W.\& Quirke, S., Festivals in the ancient Egyptian calendar, Digital Egypt for Universities, University College London. Retrieved 31 October, (2015)

${ }^{9}$ Reisner, G., 'The Tomb of Hepzefa, Nomarch of Siût', JEA 5, (1918), pp. 79-98. 
$r n b t, m s y t, w^{3} g .{ }^{1}$ Spalinger adds that this classification is unusual and appears to reflect a local tradition at Meir. ${ }^{2} \quad$ Close parallels were attested at least with another Abydene example (stela Munich GL WAF 35; Leiden V4 stela from Naga-ed-Der (UE 8) Metropolitan Museum 25.2.3; Dunham, Naga-ed-Der, no. 83, pp. 107f, pl. XXIV; Stela of Rediu- Khnum Cairo 20543).

Five Epagomenal Days: the Epagomenal days are five days over the year' (= days 361365 of the official year, added to the 12 months), they were not part of the normal year created by the gods. Five children were born on these days: Osiris, Horus, Seth, Isis and Nephthys. ${ }^{3}$ The Msyt feast was after the Epagomenal days but before $w 3 g$, designating the night preceding the first day. It was observed that Anubis offering formulae more attached to msyt which always follows $w 3 g$ feast. ${ }^{4}$

The W3g- festival: ${ }^{5}$ it was an old festival fo beginning of the inundation ${ }^{6}$ on the $17^{\text {th }}, 18^{\text {th }}$ and $19^{\text {th }}$. The latter date, i.e. $19^{\text {th }}$ was also Thoth's festival ${ }^{7}$, according to the great festival list in the temple for Ramesses III at Medinet Habu. ${ }^{8}$ Parker has confirmed that this feast, according to Illahun papyri, celebrated on the $18^{\text {th }}$ of the first civil month. ${ }^{9}$ Most Middle Kingdom coffins replaced the name of the festival with a clause containing the verb w3gi. However, the Pyr \& 716c had the name of the festival which occurred later on some Middle Kingdom coffins. Moreover, even the adapted readings from the Middle Kingdom must refer to the festival cf. Pyr \& 2185a-b: "w3g yourself with bread just like Horus "w3g-ed" his Eye in this name of $W 3 g$ - festival", the verb $w 3 g$ here obviously has some such sense as "to provide" cf. Pyr. \&192a; \& 1944c; \& 2114a; \& 2230b; \& 2289 b; cf. Stela Louvre (c 35) mentions the $w 3 g$ festival and alludes to other festivals which Osiris crosses from the great Gat of Haker, cf. also stela CG. 20546, a 4-5; Pyr. \& 820a. CT III, 159b; CT III, $158 \mathrm{c}-159 \mathrm{~b}$.

\footnotetext{
${ }^{1}$ Blackman, Meir III, pls. IV, XIII, XVI; Willems, H., chests of life A study of the typology and conceptual development of Middle Kingdom standard class coffins, (Ex Oriente Lux 1988), pp. 85, 87, 91 and note 162 .

${ }^{2}$ Spalinger, A., The Private Feast lists of Ancient Egypt, Äg. Abh 57, Wiesbaden (1996), p. 47, note.2.

${ }^{3}$ Spalinger speaks also about msyt tpyt, which could refer to the feast of msyt which took place on the last day of the final Egyptian month and hence immediately preceded the birth of Osiris, the connection between msyt tpyt and mswt Wsr should at least be clear from their closeness in time see more in: Spalinger, A., Feast Lists, p. 60; id., 'Some Remarks on the Epagomental Days in Ancient Egyp't, JNES 45, N.1 (Jan., 1995), pp. 33-47.

${ }^{4}$ Willems, Chests of life, p. 91 (no. 29).

${ }^{5}$ The name of this festival appeared in the tomb of Mtn; Junker, Giza II, 62; also in Pyramid texts; Pyr. 716.820. 1880. 2185for more details see: H. Goedicke, Wag-Fest, 1135-1139.

${ }^{6}$ Feasts of Ancestors are held until now by many cultures throughout the world in honor or recognition of deceased members of the community; Barguet, P., 'Religion de l'Égypte. La fête-ouag', École pratique des hautes etudes, Section des sciences religieuses. Annuaire (1958-1959), pp. 70-76.

${ }^{7}$ The order of $W 3 g$ precedes the feast of Thoth confirmed from many texts; Urk. VII 56.14; 15-16; cf. statue of Imn-m-h3t BM 462a rather detailed feast list dated to C. Senwsert I/ Amenemhet II: 3bd, smdt, w3gy, dhwty hb-wr, hb skr.

${ }^{8}$ Schott F., Altägyptische Festdaten, Mainz, (1950), p. 39 ff.; Parker, A., the Calendars of Ancient Egypt, Studies in Ancient Oriental Civilization 26, (1950).

${ }^{9}$ Parker also stated that there was a movable feast as well as a fixed $W 3 g$ feast in the Middle Kingdom, 182.
}

- 118 - The Mortuary Chapel of Ukhhotep Son of Ima (A. No.3) at Meir 


\section{GENERAL COMMENTS}

Egyptians believed that the name should remain for the individual's memory; they built tombs ${ }^{1}$, containing the body in the substructure while the superstructure contained the false doors, chapels which usually include statues and offering table ${ }^{2}$. The offerings focused on the tomb in the Middle Kingdom. In general, the purpose of the false doors, chapels, and many texts indicate that they were to maintain the needs of the deceased of offerings and keep his memory alive. ${ }^{3}$ The chapel whether it was attached to the tomb or not represented a mean for the living to communicate with the dead people ${ }^{4}$. Chapel was a place for interaction with those who might present offerings and say prayers where ceremonies are enacted before the statues. The different texts places emphasis on this feature:

$\underline{d}$ d.tn n.i $t$ hnkt $m-n t t ~ m$ - $^{\top} . \underline{n} n$ "so may you give to me bread and bear from what is with you"

f33.tn $m$ 'wi.tn "may (you) elevate with your arms"

wdn.tn $m$ r 3.tn "may you offer with your speech". 5

dd.k3.tn $m$ r.tn wdnw $m^{c}$.tn "you shall say with your mouth and offer with your hand". ${ }^{6}$

The Egyptian religion emphasized the importance of the family as a very important unit. For example, the ennead of Heliopolis set forth as a family group and in order of seniority, which goes along with the document Teaching of Duaf's son Khety from the Middle Kingdom, the author tells his son to "thank God for your mother and for your father, who put you on the path of life". This chapel also shows the affection and respect from a son to his father, which reflects the loyalty and respect to the father in the ancient Egyptian society. Kees, pointed out that these feasts were connected with the desire of the tomb owner to be associated with his family, and priests at specific religious on holidays ${ }^{7}$. Males had more reasonable issue in providing the offerings and ensuring the performance of rituals for their dead fathers. ${ }^{8}$ This action was closely linked to the Osirian mythical narrative where the divine son, Horus, fulfills the funerary needs and mortuary cult of his murdered father, Osiris. The explanation of Horus and his defense

\footnotetext{
${ }^{1}$ The Egyptians expressed their desire to build the tomb by saying: "it will not perish from the land forever" Lichtheim, Literature, vol.2, p. 12.

${ }^{2}$ Brovarski, E., The Doors of Heaven, Orientalia 46, (1977), pp. 107-115.

3 another point of view is that: the individual should survive in social memory rather than through his monument. The most important early skeptical statement is that of the Middle Kingdom Instruction foe Merikare see: Parkinson, The Tale of Sinuhe and Other Ancient Egyptian Poem, Oxford, (1988), p. 229.

${ }^{4}$ Muller M., Feasts for the Dead and Ancestor Veneration in Egyptian Tradition, in Herrmann V. and Schloen, J. (eds.), Remembrance of me: Feasting with the Dead in Ancient Middle East: Chicago: The Oriental Institute of the University of Chicago, (2014), p. $86 \mathrm{f}$; and the recent study: Rémi Legros, Stratégies mémorielles. Les cultes funéraires privés en Égypte ancienne de la Vie à la XIIe dynastie, Lyon, ( 2016).

${ }^{5}$ Baines, J., 'Self-presentation of Pepyankh the Middle at Meir' in Louts and Laurel: Studies on Egyptian Language and Religion in Honour of P. Frandsen, CNI Publications 39 , (2015), p. 26.

${ }^{6}$ Drioton, ASAE 43 (1943), p. 503. see also Urk. I, 197, 13-15.

${ }^{7}$ Kees, H., Totenglauben und Jenseitsvorstellungen der alten Ägypter, Berlin, (1956), 120-21; Junker notes that these feast days would be celebrated in the necropolis itself; Junker, Giza II, p. 61.

${ }^{8}$ For the use of: $n$ it.f 'his father', see also L. A. Flentye, The Decorated Elite Mastaba and Rock-cut Tomb in the Eastern and GIS Cemeteries at Giza and their Relationship to the Development of Art during the Fourth Dynasty (PhD diss., New York University, 2006); about the designations of the relationship of the Family relatives in the Middle Kingdom cf. Franke, D., 'Altagyptische verwandtschafts bezeichnungen im Mittleren Reichs', Ḧ̈S 3, (Hamburg 1983).
} 
of his father gave meaning and form to the world beyond the grave ${ }^{1}$. The chapel A3 may be served as a place for family gathering in order to address the deceased and keep his memory alive among the living and provide essential provisions for him in the afterlife. From an elite perspective, another benefit from the visitors to these chapels was of course wider than that of temple priests, including women, servants, children, and public in general who ask for help. Any visitor, who can read, could activate the formula, inscribed and embedded within the offering imagery at this chapel ${ }^{2}$. Mortuary rites spoken or enacted by a ka-priest, was usually represented by an elder son of the deceased ${ }^{3}$.

\section{GENEALOGY OF UEKHHOTEP (A3)}

Difficulties are encountered in determining the absolute genealogy of Ukhhotep (A3) due to the names Ukhhotep along with Snbi, are the most popular and repeated names in Meir. The name of Ukhhotep was well attested in the Middle Kingdom. It was

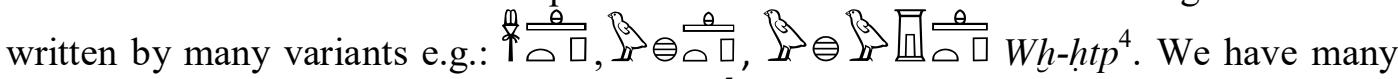
Ukhhotep; Ukhhotep son of Snbi, (tomb B2) ${ }^{5}$, Ukhhotep was a son of Ukhhotep (tomb B4) ${ }^{6}$, Ukhhotep (tomb C1) ${ }^{7}$, in the same site, we have the Tomb of Wh-htp son of Wh-

\footnotetext{
${ }^{1}$ Quirke, S., Ancient Egyptian Religion, London (1992), pp. 52-61, 66; Dr. N. Kanawati told me (personal communication) that the reason why the tomb A3, which is the subject of my article, is positioned in an area that must have been considered as a remarkable example of filial affection. The tomb is above tombs A1 of Niankhpepy the Black and A2 of his son Pepyankh the Black. In fact Niankhpepy excavated a huge tomb, A4, but died after preparing its walls for decoration, and before any scenes or inscriptions were executed. His son Pepyankh excavated and decorated a burial chamber for his father in tomb A4, then he cut the two adjoining tombs A1 and A2. The former was for his father and the latter for himself, and connected the burial chamber of tomb A4, where the father is buried to the chapel of A1 by a plopping passage. This would allow the father to communicate between tomb A4 where he is buried and the chapel of A1 in order to receive offerings and to communicate with his son in their communicating chapels A1A2. This case is to a large extent similar to the contemporary one of Djau and his father Djau/Shemai of Deir el-Gebrawi, who was even buried in the same tomb. The son wrote that he buried his father with him in order to be able to see his father every day and to be with him at the same place. Deir el-Gebrawi is very close to Meir and the two cases of father-son affection must have been well known at el-Qusiya. Perhaps Ukhhotpe's selection of the site was to demonstrate the type of affection which he had for his father) for the tombs A1 and A4 see: Kanawati, Meir III. Another example from Meir reflects a sort of loyalty between father and son. The tomb of UKhhotep II (B2) is separated from that of Ukhhotep II, s ????father Senebi 1 B1) only by a thin partition wall; Altenmüller, H. 'Family, Ancestor Cult and some Observations on the Chronology of the Late Fifth Dynasty.' in H. Vymazalová and M. Bárta (eds), Chronology and Archaeology in Ancient Egypt (The Third Millennium B.C.). Proceedings of the Conference Held in Prague (June 11-14, 2007), (Prague. 2008). 144-161.

${ }^{2}$ Baines, J. \& Lacarova, P., 'Burial and the Dead in Ancient Egyptian Society', Journal of Social Archaeology 2/1, (February 2002), pp. 5-35(Online p. 12) http://jsa.sagepub.com/cgi/content/abstract/2/1/5

${ }^{3}$ The ritual of opening the mouth perhaps took place in the time of Amenhotep I in the chapel of the tomb, but it may be experienced in this place starting from the middle kingdom Otto, Mundöffnungsritual II, p.8. ${ }^{4}$ Ranke translated the name "der Gott $w h$ ist gnädig"; Ranke, $P N$ I, 84, 9. 10; II, 35. 36. 45. 69. Other

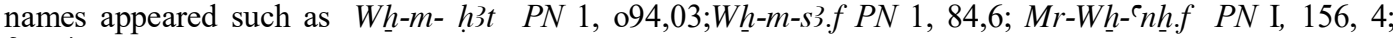

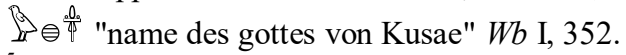

${ }^{5}$ Blackman, Meir II; PM IV, 250-251

${ }^{6}$ Blackman, Meir III; PM IV, 251-253.

${ }^{7}$ It is possible that the owner of tomb A4 provides the link between Ukhhotep of $\mathrm{C} 1$ and the earlier rulers of this district: Blackman, Meir VI, 8-37; PM IV, 253;Martin, E.,LÄ VI, 821-822. ).Kanawati disagrees with most scholars in the number of the governors of Meir, as he gives numbers only to those who governed the province and not to anyone who was called Ukhhotep: Ukhhotep I (B2), Ukhhotep II (B4), Ukhhotep III (C1) (personal communication).
}

- 120 - The Mortuary Chapel of Ukhhotep Son of Ima (A. No.3) at Meir 
$h t p$ and $M r-s)^{1}$. The dating of the members of nobility at Meir was discussed from Old Kingdom $^{2}$ to the Middle Kingdom ${ }^{3}$. Ukhhotep son of Ukhhotep (B4) came from a big family. He had at least three brothers who also were called Ukhhotep ${ }^{4}$. A very important list of counts $h 3 t y w$ - $^{-}$of this nome is recorded in his tomb, but unfortunately it is partly damaged and no fixed dates are given ${ }^{5}$. It once depicted 59 persons (with their wives) holding the title h3ty-?. The purpose of their inclusion was clarified as he stated that: ir.n.i $n w n$ mrwt wnn rnw.sn $n \underline{d} t$ "I did this in order that their names endure forever" ${ }^{6}$. A name and an epithet, $m 3^{\top} \underline{h r w}$, were given to each figure. With regard to the identity of Ukhhotep Oof A3 and his relationship to the other officials who bore the same name ${ }^{7}$; the second figure in the fifth register of the counts list mentioned $h 3 t y^{\circ} 13 \mathrm{~m}$, suggests to be the father of the h3ty-` Ukhhotep A3. Iam must be a h3ty-' because his son is the son of h3ty- ${ }^{8}{ }^{8}$. Gillam, in her dissertation on the $14^{\text {th }}$ Upper Egyptian nome, stated that in all discussions of individual titularies, titles are assumed in the absence of any definite indications to have been held simultaneously with each other. This is not entirely satisfactory, but the nature of our data leaves us with no choice, ${ }^{, 9}$

I regard simply that Ukhhotep of A3 as perhaps the ancestor of the family and one of the earliest of the Middle Kingdom, and perhaps he was buried in section A, close to the officials of Old Kingdom and away from those of the Middle Kingdom in section B and C. But unfortunately, genealogy is not much of an aid in determining absolute chronology of the owner of A3. There is no clear connection whereas no document was found in the necropolis that provides an absolute genealogy.

\section{DATE OF THE CHAPEL}

In general, the chronology of the rulers of the $14^{\text {th }}$ upper Egyptian Nome who were buried at Meir is clearer than the other Middle Kingdom monarchs. This recent article places emphasis on the importance of counting the generations in determining the chronology of the monarchs of el-Qusiya at the end of the First Intermediate Period and the beginning of the Middle Kingdom. Five tombs confirmed with royal dates of Twelfth Dynasty, namely the tomb of Senbi I (B1), Ukhhotep (B2), Senbi II (B3), Ukhhotep (B2) and Ukhhotep (B4) Ukhhotep (C1) ${ }^{10}$. As for Blackman, he dated the

\footnotetext{
${ }^{1}$ Blackman, Meir II, pls. IV, XIII, XVI; Grajetzki, W., The Middle Kingdom of ancient Egypt: history, archaeology and society. London: Duckworth Egyptology (2006), p. 108.

${ }^{2}$ Kanawati, N., 'Chronology of the Old Kingdom Nobles of el-Qusiya Revisited', in Z. Hawass, P. Der Manuelian and R. Hussein, eds., Perspectives on Ancient Egypt; Studies in Honour of Edward Brovarski, CASAE 40 (Cairo, 2010), pp. 207-220.

${ }^{3}$ For discussion of the role of the regional governors in the reign of Senwosert I, see Favry, N., Le nomarque sous le réne de Sésostris Ier, les institutions dans l'Eypte ancienne 1, Presses de L' Université Paris-Sorbonne Paris, (2004).

${ }^{4}$ Blackman, Meir III, pl. 22.

${ }^{5}$ Bierbrier M., 'Genealogy and chronology', in E. Hornung, R. Krauss and D. Warburton, eds., Ancient Egyptian chronology, (Leiden/Boston 2006), p. 40; Blackman, Meir III, pp. 16-21, pls. 10-11; Chassinat, ??? 'Notes prises á Meir', RT 22 (1900), pp. 76-77.

${ }^{6}$ Blackman, Meir III, pls. 11, 29.

${ }^{7}$ Kanawati has published an article on the governors of Meir, but he disagrees with most scholars in numbering the governors, as he gives numbers only to those who governed the province and not to anyone named Ukhhotep. Therefore to him Ukhhotep I is (B2), Ukhhotep II is (B4), Ukhhotep III is (C1)

${ }^{8}$ Eavry, N., The transmission of offices in the Middle Kingdom in G. Miniaci, W. Grajetzki, eds., Middle Kingdom Studies, vol.2, (London 2016), p. 129ff.

${ }^{9}$ Gillam, R. A.. Topographical, Prosopographical and Historical Studies in the $14 t h$ Upper Egyptian Nome. Unpublished PhD Dissertation, University of Toronto (1991).

${ }^{10}$ Doxey, Non Royal Epithets, p. 11.
} 
chapel from Senwosert I to Amenemhat II $^{1}$. Holzl didn't specify a date but placed it generally in the Middle Kingdom ${ }^{2}$. Willems pointed out that the chapel dates to the Old Kingdom but it was not finished ${ }^{3}$ (the later hypothesis seems to be not acceptable at present because there are many doubts).

Preliminary analysis of the chapel structure, offering formula, and archaeological context $\mathrm{s}$ dates the chapel to Senwosert $\mathrm{I}^{4}$. The paleography of the hieroglyphs seems to point to a date in the Twelfth Dynasty. The offering formula was considered a characteristic aspect for the first part the Twelfth Dynasty by C. Bennett ${ }^{5}$. In the offering formula, the name of Osiris was written bythe determinative of a seated god, which is more common in early Middle Kingdom ${ }^{6}$. O. Berlev remarks that the request of "every pure thing/ all pure things" (also in line 2, above) is typical in the Eleventh Dynasty and the reign of Senwosert I, whilst later the most frequent phrase is "all good and pure things", and before the Twelfth dynasty but also at the end of it "all good things" is used. $^{7}$ The $\mathrm{n}$ of dative was attested before the epithet $m 3^{r}$ hrw during the Herakleopolitan Period up to the Twelfth Dynasty. There are similarities in dedicatory inscription parallels between that found in tomb B3 (Senwosert I) ${ }^{8}$. The date is in agreement with that proposed by a number of scholars; but further examination would be needed to refine this proposed date. The same applies to the social standing and career of the tomb owner: there is no preserved titles on this chapel except the general one h3ty 3 suggest a middle-class standing. However, analysis of other finds and archaeological contexts would provide a clearer picture of his career and social standing 9. It remains to ask: why this chapel which dates to the Middle Kingdom was cut 1 over the tomb of Pepyankh ${ }^{10}$ (Old Kingdom)? I suggest that Ukhhotep choose this location for these reasons: firstly, this place was the cult center of Hathor, secondly due to the dignified Pepyankh A2 and his religious status for his public priestly role ${ }^{11}$. He also mentions in his texts that he inaugurate the Meir cemetery ${ }^{12}$. It is clear that the Egyptians practiced some form of ancestor worship around his tomb ${ }^{13}$.

${ }^{1}$ Blackman, Meir VI, p. 2; Kahlbacher, A., Raumfunktion und Dekorationsprogramm der Felsgräber des Alten und Mittleren, Reiches, (Ph.D. diss. University of Vienna 2011).

${ }^{2}$ Hölzl, C., Studien zur Entwicklung der Felsengräber: Datierung und lokale Entwicklung der Felsengräber des Mittleren Reiches in Mittelägypten, (1984), p. 112.

${ }^{3}$ Willems, Chests of Life, p. 85.

${ }^{4}$ Another assumption proposed that the chapel dates to Amenemhat I, as there are few dated sources from the reign of Amenemhat I.

${ }^{5}$ Bennett, C., JEA 27 (1941), pp. $77 \mathrm{ff}$.

${ }^{6}$ Bennett, C., JEA 27 (1941),, p.78.

${ }^{7}$ Berlev O., Odin iz sposobov datirovki stel Srednego tsartsva (Formula "O zhivie, sushchiena zemle...), Kratkie soobshchenia Instituta narodov Asii, 46, Drevniy Vostok, (1962), pp.45-87, \& 4.(Italian translation available online: www.archaeogate.org/egittologia/article/240/1/un-metodo-di-datazione-dellestele-del- medio-regno-di-o.html, (accessed 18/6/17)

${ }^{8}$ This was perhaps completed by Ukhhotep of B4.

${ }^{9}$ Perhaps the burial equipment can assist us in dating this tomb; Hayes observes that Ukhhotep's canopic box is very like that of the steward Snbi found in B3 Hayes, Scepter, p. 321.

${ }^{10}$ Blackman, Meir IV, pls. IV, IVa,V; Kanawati, Meir I; PM IV, 254.

${ }^{11}$ There are signs from his tomb showing how he was venerated, and had a holy status as: the figure of Pepyankh and his wife are seen on block thrones, normally reserved for royalty and deities; Kanawati, Meir I, pls.3, 6, 7. His privilege was also due to being the priest of the goddess Hathor i; Lichtheim, Autobiographies, p. 9. He also mentioned" ii.n.i $r$ s sk wi i3i.ki nfr wrt" "I came to it (the tomb) when I had become old very perfectly": Janssen, J., 'On the Ideal Lifetime of the Egyptian', OMRO 31 (1956), pp. 33-39. All that reflect his capacity to offer advantages from the next world to those who will perform ritual acts on his behalf see more Baines, J., Self-Presentation, p. 40.

${ }^{12}$ Kanawati, Meir I, p. 25.

${ }^{13}$ Fitzenreiter, M., 'Zum Ahnenkult im Ägypten', GM 143 (1996), pp. 51-72; Assmann, J., 'Das Bild des Vaters im alten Agypten' in: H. Tellenbach, ed., Das Vaterbild in Mythos und Geschichte, (Stuttgart

- 122 - The Mortuary Chapel of Ukhhotep Son of Ima (A. No.3) at Meir 


\section{ACKNOWLEDGMENT}

I am very grateful to Prof. N. Kanawati, for his valuable remarks on the present text. I also would like to thank Dr. Sameh Shafik for inking the inscriptions. Thanks go to Samir Homda, inspector of antiquities SCA, for his help.

\section{REFERENCES}

- Assmann, J., 'Das Bild des Vaters im alten Agypten' in: H. Tellenbach (ed.), Das Vaterbild in Mythos und Geschichte, (Stuttgart 1976), 25-38.

- Baines, John , 'The Self-presentation of Pepyankh the Middle at Meir: Scandal, Religious Institutions and Participation, the Next World', in Nyord, Rune; Kim Ryholt (eds.), Lotus and Laurel: Studies on Egyptian language and religion in honour of Paul John Frandsen, Copenhagen: Museum Tusculanum Press (2015),19-43.

- Barta, W., Die altagyptische opferliste von der Frühzeit bis zur griechisch-römischen Epoche MÄS 3, (Berlin 1963).

- _ _ Aufbau und Bedeutung der altägyptischen opferformel, Äg Fo 24, (Gluckstadt 1968)

- Barguet, P. 'Religion de l'Égypte. La fête-ouag', École pratique des hautes etudes, Section des sciences religieuses. Annuaire (1958-1959), 70-76.

- Bierbrier, Blackman, A.M. The rock tombs of Meir: Part II: The tomb-chapel of Senbi's son Ukh-Hotp: (B, no. 2), Egypt Exploration Society, London (1915).

- Blackman, A.M. (The rock tombs of Meir: Part. III: The tomb-chapel of Ukh-Hotp son of Ukh-Hotp and Mersi: (B, no. 4). Egypt Exploration Society, London (1915).

- _ The rock tombs of Meir: Part IV: The tomb-chapel of Pepi'onkh the middle son of Sebkhotpe and Pekhernefert (D, no. 2, Egypt Exploration Society, London (1924).

- _ The rock tombs of Meir: Part V, Egypt Exploration Society, London (1953).

- _ (1953)

- _ The rock tombs of Meir: Part I: The tomb of Pepyankh the middle, Egypt Exploration Society, London (1914).

46 (1977), 107-115.

- DoxeyD., Egyptian Non - Royal Epithets in the Middle Kingdom, (London-1998)

- Favry, N., Le nomarque sous le réne de Sésostris Ier, les institutions dans l'Égypte ancienne 1, Presses de L'Université Paris-Sorbonne (Paris 2004).

- Franke , D., 'The Middle Kingdom offering formulas- a challenge', JEA 85 (2003), 39-57.

- Gillam, R. A., Topographical, Prosopographical and Historical Studies in the 14t $h$ Upper Egyptian Nome. Unpublished PhD Dissertation, University of Toronto (1991).

- Grajetzki, R., The Middle Kingdom of ancient Egypt History, archaeology and society, London-Duckworth Egyptology (2006),

- Hölzl, C., Studien zur Entwicklung der Felsengräber: Datierung und lokale Entwicklung der Felsengräber des Mittleren Reiches in Mittelägypten, (1984)

1976), pp. 12-50; id.,'Die Zeugung des Sohnes: Bild, Spiel, Erzahlung und das Problem des agyptischen Mythos' in J. Assmann, W. Burkert, F. Stolz, eds., Funktionen und Leistungen des Mythos. Drei altorientalische Beispiele OBO 4 (1982), pp. 13-61. 
- Janssen, J, 'On the Ideal Lifetime of the Egyptian', OMRO 31 (1956), 122-134

- Jansen, K. W., 'Zur Bedeutung von imAx', Bulletin de la Societé d'Égyptologie de Genève 20 (1996), 29-36

- Kahlbacher, A. Raumfunktion und Dekorationsprogramm der Felsgräber des Alten und Mittleren, Reiches, (Ph.D. diss. University of Vienna 2011)

- Kanawati, N., 'Chronology of the Old Kingdom Nobles of el-Qusiya Revisited', in Z. Hawass, P. Der Manuelian and R. Hussein (eds.), Perspectives on Ancient Egypt; Studies in Honour of Edward Brovarski, CASAE 40 (Cairo, 2010), 207-220.

- Kanawati, N. and Evans, L., The cemetery of Meir I: The tomb of Pepyankh the Middle. Oxford: Aris and Phillips (2012).

- _ The cemetery of Meir II: The tomb of Pepyankh the Black. Oxford: Aris and Phillips (2014).

- Kees, H., Totenglauben und Jenseitsvorstellungen der alten Ägypter, (Berlin 1956).

- Porter, B.\& Moss, R., The Digital Topographical Bibliography of Ancient Egyptian Hieroglyphic Texts, Statues, Reliefs, and Paintings, volume 4. Oxford: Clarendon Press (1988).

- Magee, D., Asyut to the End of the Middle Kingdom: A Historical and cultural study, Ph.D. Thesis, Oxford (1988).

- O'Connor, D., 'Society and Individual in Early Egypt'. In Richards, Janet E. and Mary Van Buren (eds.), Order, legitimacy, and wealth in ancient states, Cambridge: Cambridge University Press (2000), 21-35.

- Quirke, S., Ancient Egyptian Religion, (London 1992)

- Raymond, J. , Cusae in Dictionnaire d'Histoire et de Géographie, vol. XIII, Paris (1956)

- Reisner, G., 'The Tomb of Hepzefa, Nomarch of Siût', JEA 5 (1918), 79-98.

- Spenser, P., Studies in the Lexicography of Ancient Egyptian buildings and their parts, (London 1981),

- Willems, H., Chests of Life: A study of the typology and conceptual development of Middle Kingdom standard class coffins, Leiden, (1988).

Willems, H., Nomarchs and Local Potentates,' The Provincial Administration in the Middle Kingdom' in C. Moreno, (ed.), Ancient Egyptian Administration, (Leiden 2013), 361-387. 


\section{Plates and Figures}

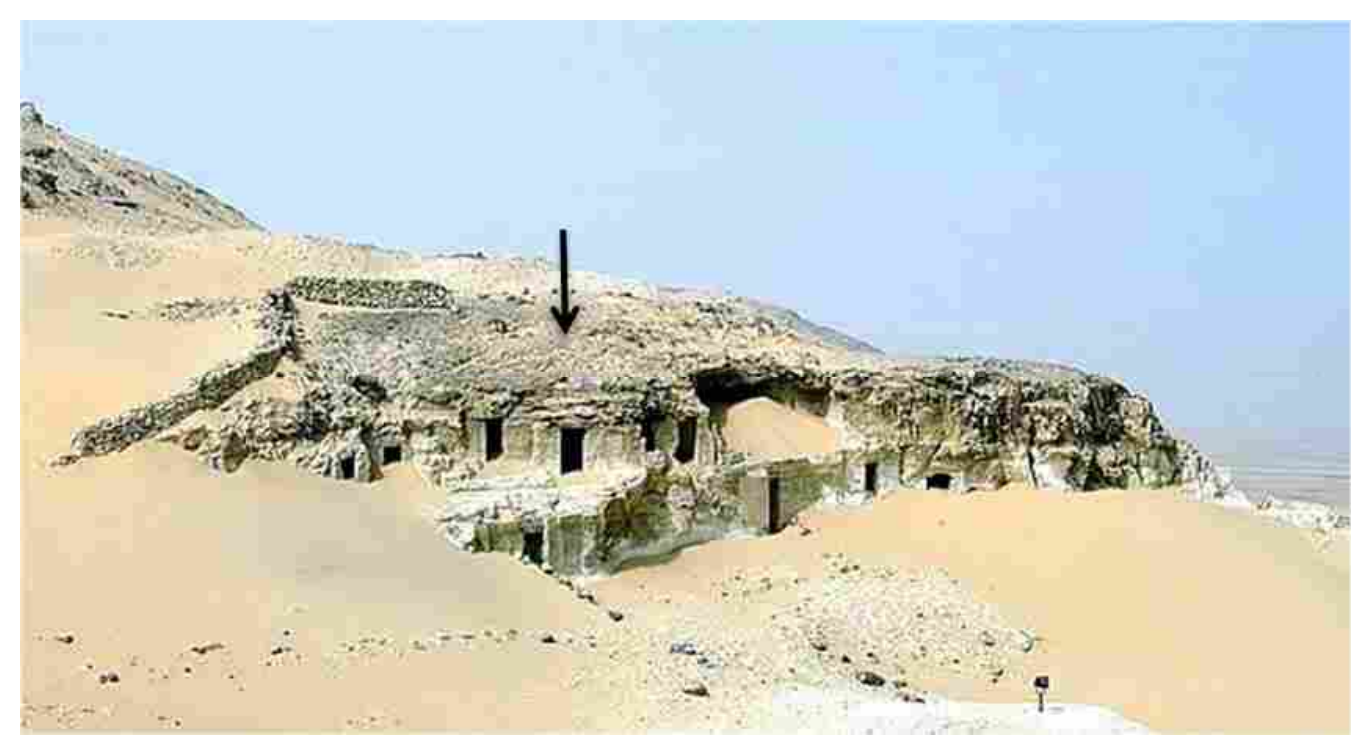

Figure 1. Meir tombs, group A - The arrow points to A3.

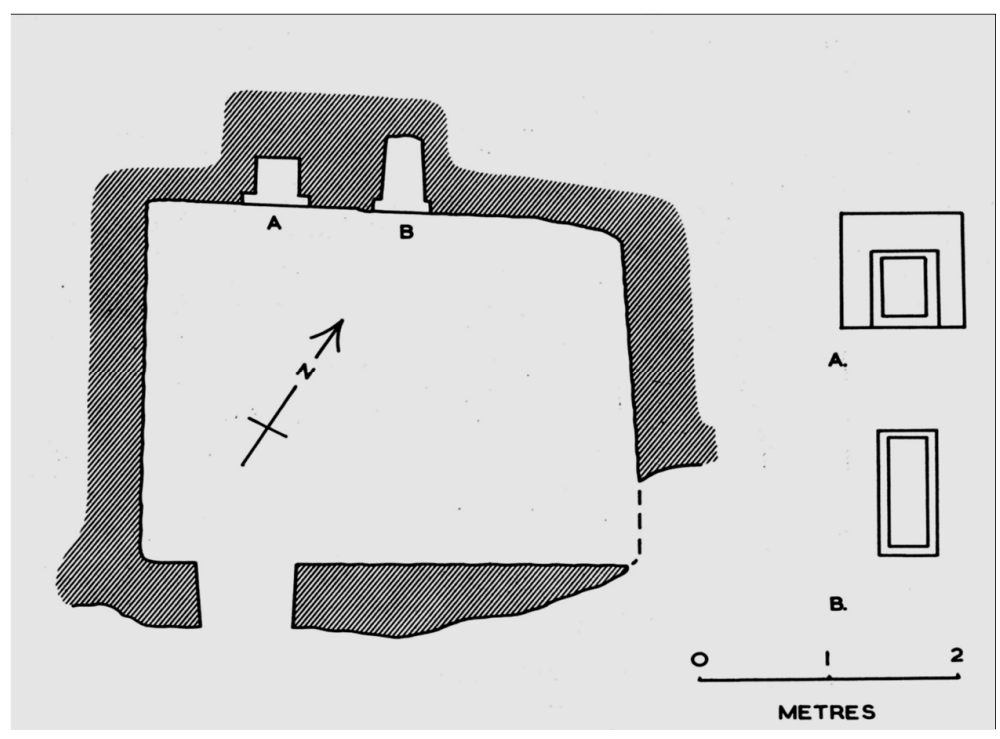

Plate 1. Tomb Chapel A. No. 3 (Blackman, Meir VI pl. 2) 


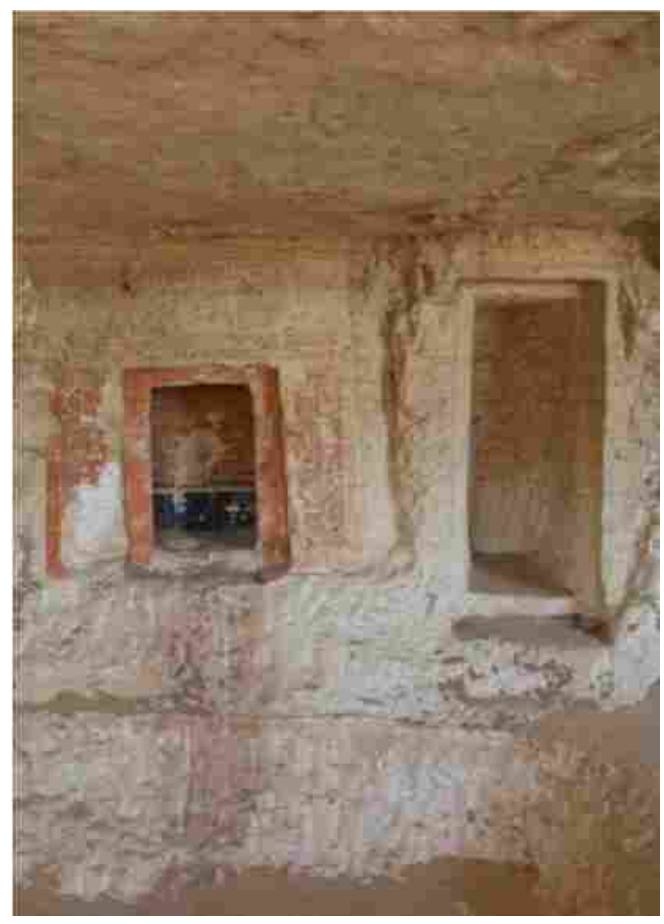

Figure 2. General View to the two recesses Inside the Chapel

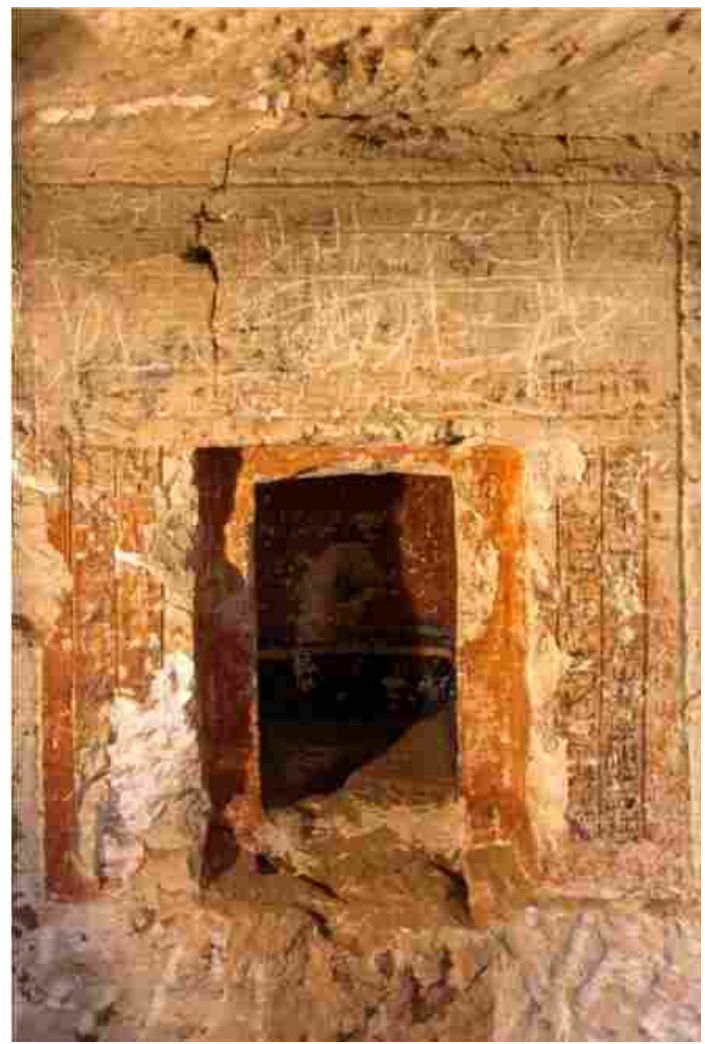

Figure 3. Text around the western recess

\footnotetext{
- 126 - The Mortuary Chapel of Ukhhotep Son of Ima (A. No.3) at Meir
} 

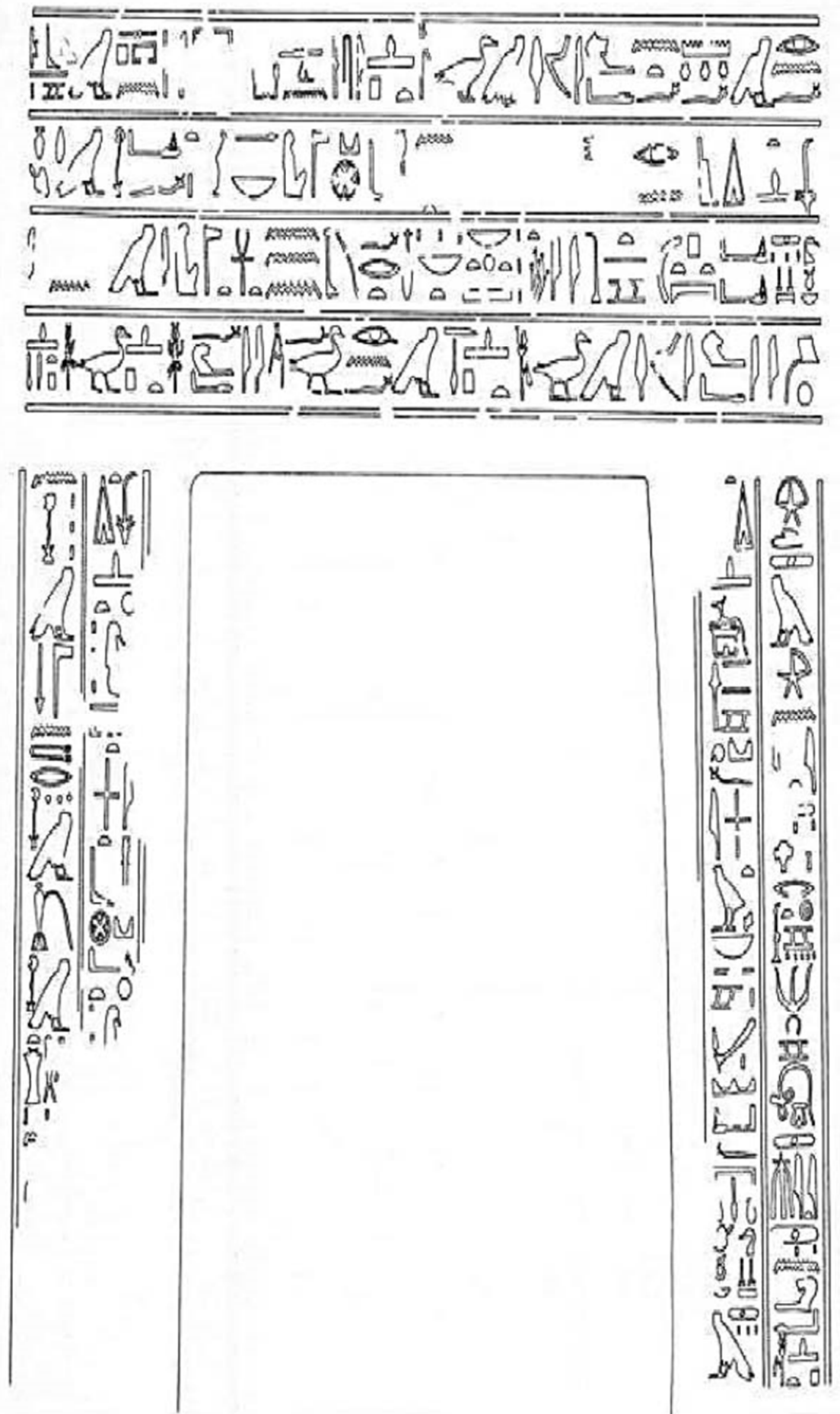

Plate 2. Chapel's Inscriptions of Ukhhotep (A3) 